\title{
Quadruplex Priming Amplification at a Range of Human Body Temperature
}

\author{
David Gvarjaladze ${ }^{1, *}(\mathbb{D})$, Tamari Gulua ${ }^{1}$, Shota Gogichaishvili ${ }^{2}$, Jozef Hritz ${ }^{3,4}$, Nunu Metreveli ${ }^{1}$ \\ 1 Institute of Biophysics, Ilia State University, Kakutsa Cholokashvili Ave 3/5, Tbilisi 0162, Republic of Georgia \\ 2 Andronikashvili Institute of Physics, I. Javakhishvili Tbilisi State University, Tamarashvili Street 6, 0177 Tbilisi, Republic \\ of Georgia \\ 3 Structural Biology, CEITEC-MU, Masaryk University, Kamenice 5, 62500 Brno, Czech Republic \\ 4 Biophysical Chemistry, Department of Chemistry, Faculty of Science, Masaryk University, Kamenice 5, 62500 Brno, \\ Czech Republic \\ * Correspondence: davit.gvarjaladze.1@iliauni.edu.ge;
}

Received: 6.06.2020; Revised: 4.07.2020; Accepted: 5.07.2020; Published: 9.07.2020

\begin{abstract}
Quadruplex priming amplification (QPA) is a very simple amplification assay in which the isothermal amplification is performed using an only DNA polymerase, and detection is conducted by the intrinsic fluorescence of the primers. QPA employs specific G-rich sequences as primers that, upon polymerase elongation at specific temperatures, spontaneously dissociate from the primer binding sites (PBS) and fold into a monomolecular quadruplex. Fluorescent nucleotide analogs, such as 3-methyl isoxanthopterin (3MI), when incorporated into these primers, emit light upon a quadruplex formation and permit simple, specific, and sensitive quantification without the attachment of probe molecules. Previously has developed QPA assays with truncated targets and potassium cations that demonstrate an optimal amplification around $55^{\circ} \mathrm{C}$. Here, we designed QPA assays with truncated target and led cations at a range of human body temperature. Lead cations reveal the most rapid amplification than potassium and strontium cations. QPA can be applied as a method for the implementation of simple and cheap diagnostics (point of care (POC)), as well as development at a range of $35-45^{\circ} \mathrm{C}$ temperature, which will make this method more convenient for using it in molecular diagnostics.
\end{abstract}

Keywords: quadruplex; DNA amplification; the point of care; lead cations; fluorescence.

(C) 2020 by the authors. This article is an open-access article distributed under the terms and conditions of the Creative Commons Attribution (CC BY) license (https://creativecommons.org/licenses/by/4.0/).

\section{Introduction}

Free energy of d(GGGTGGGTGGGTGGG) (G3T) quadruplex can be used to drive isothermal amplification of DNA, or Quadruplex Priming Amplification (QPA)[1]. QPA allows isothermal amplification of nucleic acids with improved yield and simplified detection. This assay is based on the G3T DNA quadruplex, which in the presence of specific cations, possesses unusually high thermal stability. The key point of QPA is that the G3T sequence is capable of forming quadruplexes with significantly more favorable thermodynamics than the corresponding DNA duplexes [2]. QPA employs truncated G3T sequences as primers, which upon polymerase elongation, self-dissociate from the binding site and allow the next round of priming without thermal unfolding of amplicons. In addition, G3T with an incorporated 3methyl isoxanthopterin (3MI) in the 4th position demonstrated a 50-fold increase in fluorescence upon a quadruplex formation, which allows simple, specific and effective quantification without extra probe molecules [3]. 3MI with excitation and emission wavelengths of $348 \mathrm{~nm}$ and $431 \mathrm{~nm}$, is a fluorescent analog of guanine, although 3MI does not 
base pair with natural nucleic-acid bases and has a high quantum yield (0.88) [4]. Upon incorporation, even in the unstructured single-stranded DNA, fluorescence is significantly quenched. This restricts wide usage of $3 \mathrm{MI}$ in nucleic acids reactions; as such, it has been mainly used to study nucleic acid loop structures (Figure 1).

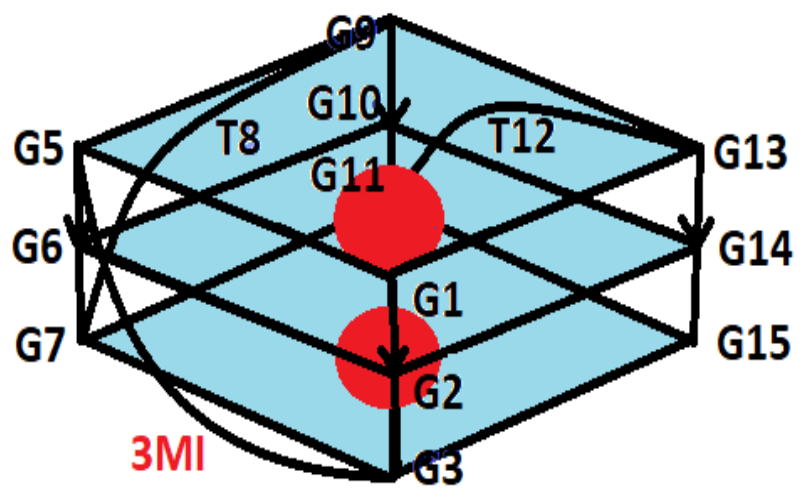

Figure 1. Graphical representation of G3T quadruplex with 3-methyl isoxanthopterin (3MI) in the 4th position, and metal ions (hypothetically, red).

As we mentioned, this assay is based on the G3T DNA quadruplex. Quadruplexes plays important roles in many biological processes [5-14] The G3T sequence is based on the DNA aptamer, which was designed against HIV-1 integrase [15]. Monomolecular quadruplexes are formed by stacks of G-quartets connected to each other by single-stranded loops. G-quartets are formed by four guanine residues associated with a square planar configuration, in which each guanine interacts with its two neighbors through hydrogen bonds ( 8 per quartet). The formation of $\mathrm{G}$-quartets requires the presence of cations (such as $\mathrm{K}^{+}$), which bind specifically to guanine O6 carbonyl groups between the planes of the G-quartets [16]. Due to the cation coordination in the center of G-quartets and stacking interactions, monomolecular quadruplexes are remarkably stable and fold readily [17]. The truncated version of G3T is not able to fold the quadruplex and perfectly hybridizes with the template, which represents a complementary sequence to G3T. A polymerase attaches missing guanines and, as a result, G3T spontaneously dissociates from its template, folds into the quadruplex, and emits light. As a result, QPA is able to amplify DNA isothermally [18], which is critical for DNA-based point of care diagnostics [19].

In this work, we designed linear isothermal QPA assays at a range of human body temperature. For this purpose, we resolved the following tasks: (i) to design primer-template complexes for QPA at this interval. (ii) To select the polymerase, which enabled to implement of QPA at this temperature. (iii) To select the cation which allows an optimal rate of QPA. Overall, the reported data creates a framework for further development and future applications of QPA in nucleic acid-based diagnostics.

\section{Materials and Methods}

\subsection{Enzymes and DNA substrates.}

DNA polymerases: Taq, Vent (exo-), and Bst 3.0 were purchased from New England BioLabs. Taq DNA polymerase is frequently used in methods for amplifying the quantity of short segments of DNA. Vent (exo-) DNA polymerase has been genetically engineered to eliminate the $3^{\prime} \rightarrow 5^{\prime}$ proofreading exonuclease activity associated with Vent DNA Polymerase [20]. This is the preferred form for high yield primer extension reactions. The fidelity of 
polymerization by this form is reduced to a level of about 2-fold higher than that of Taq DNA Polymerase [21, 22]. Bst 3.0 DNA polymerase is an in silico designed homolog of Bacillus stearothermophilus DNA polymerase, Large Fragment engineered for improved isothermal amplification performance and increased reverse transcription activity.

DNA oligonucleotides were obtained from Integrated DNA Technologies and Fidelity Systems. All measurements were performed in a buffer solution consisting of $10 \mathrm{mM}$ Tris- $\mathrm{HCl}$ at $\mathrm{pH}$ 8.7.

\subsection{UV-Visible spectroscopy.}

Temperature-dependent UV-Visible spectroscopy is a convenient tool to study secondary structure, thermal stability, and estimate van't Hoff thermodynamics of DNA or RNA molecules. UV-Visible spectroscopy is traditionally used to monitor thermal unfolding experiments of nucleic acids. Specifically, the unfolding of DNA duplexes is accompanied by an increase in absorbance at $260 \mathrm{~nm}$, and accurate determination of the thermodynamic parameters for quadruplexes is possible by monitoring the long-wavelength region of the UV spectrum ( 295 nm) [23-26]. UV unfolding experiments allowed an estimation of the melting temperature of the quadruplex and the van't Hoff enthalpy, $\Delta H_{\mathrm{vH}}$. Melting temperatures were determined by recording UV absorption at $\sim 295 \mathrm{~nm}$ as a function of temperature using a Varian UV-visible spectrophotometer (Cary $100 \mathrm{Bio}$ ) at using $\sim 4 \mathrm{M}$ G3T oligonucleotide solutions in $1 \mathrm{~cm}$ cells. In a typical experiment, oligonucleotide samples were mixed and diluted into the desired buffers in Quartz cuvettes. After annealing by heating to $97{ }^{\circ} \mathrm{C}$, the temperature was ramped to the desired starting temperature, $4 \mu \mathrm{M} \mathrm{PbCl}_{2}$ or $4 \mu \mathrm{M} \mathrm{SrCl}_{2}$ or $100 \mu \mathrm{M} \mathrm{KCl}$ were added, and the melting experiments were performed at a heating rate of $1{ }^{\circ} \mathrm{C} / \mathrm{min}$. The UV melting curves allowed an estimate of melting temperature, $\mathrm{Tm}$, the midpoint temperature of the unfolding process, van't Hoff enthalpies $\Delta H_{v H}$, were also calculated using the following equations:

$$
\Delta H=6 \mathrm{R} T m^{2} \frac{\delta \alpha}{\delta \mathrm{T}}
$$

in the case the same concentration of G3T and cations $\left(\mathrm{Pb}^{2+}\right.$ or $\left.\mathrm{Sr}^{2+}\right)$ and

$$
\Delta H=4 \mathrm{RTm}^{2} \frac{\delta \alpha}{\delta \mathrm{T}}
$$

in the case of $\mathrm{K}^{+}$cations, $\sim 25$ times more than a concentration of G3T and concentration of unbound $\mathrm{K}^{+}$cations in a solution can be considered constant. R is the gas constant, and $\delta \alpha / \delta \mathrm{T}$ is the slope of the normalized optical absorbance versus temperature curve at the $\operatorname{Tm}[27,28]$.

\subsection{CD spectroscopy.}

$\mathrm{CD}$ (Circular Dichroism) spectroscopy is a sensitive technique for estimating secondary structure and the folding topology of DNA quadruplexes. By comparing CD spectra with NMR or X-ray structures of simple GT-containing sequences, the following features are observed: parallel quadruplexes, which are structures with all four G-tracts having the same orientation, are characterized by a positive peak at $\sim 265 \mathrm{~nm}$ and a negative peak at $\sim 240 \mathrm{~nm}$ [29-31]. In addition, characteristics of parallel quadruplexes also include a minor positive peak at $\sim 305 \mathrm{~nm}$ [29, 32-35]. Antiparallel quadruplexes demonstrate positive CD bands with maxima at 245 $\mathrm{nm}$ and $\sim 295 \mathrm{~nm}$ and a negative peak at $\sim 265 \mathrm{~nm}[36,37]$. CD spectra were recorded by a JASCO Spectrophotometer in $0.5 \mathrm{~cm}$ Quartz cuvette, the concentration of G3T $\sim 2 \mu \mathrm{M}$. 


\subsection{Fluorescence spectroscopy.}

Fluorescence spectroscopy is one of the most sensitive tools. Fluorescence has traditionally been used to monitor the activity of various enzymes, quantify DNA amplification, to study molecular interactions and dynamics. In our assays, we use fluorescence analog of nucleotides (e.g., 3MI), which are completely quenched in singlestranded or double-stranded DNA, and emit light upon quadruplex formation.

Fluorescence measurements were performed using an ESEQuant Tube Scanner (Qiagen). QPA reactions were carried out in a reaction mixture (volume: $0.1 \mathrm{~mL}$ ) containing $300 \mathrm{nM}$ primer, $3 \mathrm{nM}$ or $1 \mathrm{nM}$ template, $800 \mu \mathrm{M}$ of dGTP, buffer $\left(10 \mu \mathrm{M} \mathrm{PbCl}_{2}, 50 \mathrm{mM} \mathrm{CsCl}\right.$, $2 \mathrm{mM} \mathrm{MgCl} 2,10 \mathrm{mM}$ Tris-HCl, and $\mathrm{pH}$ 8.7) and 0.05 unit/ $\mu \mathrm{l} \mathrm{Taq}$ or 0.08 unit/ $\mu 1$ Bst 3 or 0.06 unit/ $\mu$ l Vent (exo-) polymerase. The reactions were carried out directly in the $0.2 \mathrm{~mL}$ PCR tubes. In a typical experiment, buffer, DNA polymerase, and dGTP were added. The fluorometer equilibrated at reaction temperature followed by real-time fluorescence monitoring.

\section{Results and Discussion}

\subsection{Primer/Template complexes for QPA at a range of human body temperature.}

To design such a primer/template complex that will allow us to implement QPA at a range of $35-45^{\circ} \mathrm{C}$ temperature is one of the most important tasks of this work. For this task, we designed the primer and three template molecules. The primer 5'GGG(3Mi)GGGCGGGTGG-3' is the modified G3T quadruplex with an incorporated 3MI in the 4th position and to which missing one guanine from 3' end. In order to avoid the undesired activity of polymerase and also to decrease $T m$, in the complexes, we applied mismatches, one mismatch in the first substrate, and two mismatches in the second substrate. The substrate 3 is without mismatches. As a result, show estimated melting temperature of substrate 2 is under $40{ }^{\circ} \mathrm{C}$ (Table 1). It gave us a good opportunity to implement QPA at a range of $35-45^{\circ} \mathrm{C}$.

Table 1. Primer/Template Complexes.

\begin{tabular}{|c|c|c|}
\hline Primer/Template Complexes & Name & $\operatorname{Tm}^{\text {a }}\left({ }^{\circ} \mathrm{C}\right)$ \\
\hline $\begin{array}{r}\text { 5'-GGG(3Mi)GGGCGGGTGG } \\
\text { 3'- ACCGCCCACCC }\end{array}$ & Substrate 1 & 45.9 \\
\hline $\begin{array}{r}\text { 5'-GGG(3Mi)GGGCGGGTGG } \\
\text { 3'- AACGCCCACCC }\end{array}$ & Substrate 2 & 38.6 \\
\hline $\begin{array}{r}\text { 5'-GGG(3Mi)GGGCGGGTGG } \\
\text { 3'- CCCGCCCACCC }\end{array}$ & Substrate 3 & 51.9 \\
\hline
\end{tabular}

${ }^{\mathrm{a}} \mathrm{Tm}$ values were estimated from nearest-neighbor analysis excluded mismatches. Concentration of Primer/Template Complexes $300 \mathrm{nM}, 50 \mathrm{mM}$ monovalent cations, $2 \mathrm{mM} \mathrm{MgCl}$.

\subsection{Optimal cations for $Q P A$.}

As we mentioned before, the cation is necessary for the formation of the quadruplex, but not all of them can form the quadruplex, or they might form the quadruplex with less stability. For example, potassium cation can form a stable quadruplex, but cesium can't. It is because that $\mathrm{K}^{+}$ions with ionic radii of $133 \mathrm{pm}$ are the optimum size for a cation to enter the inner core of G-quartets while $\mathrm{Cs}^{+}$ions with ionic radii of $169 \mathrm{pm}$ are too big [15,38,39]. Thus, $\mathrm{Cs}^{+}$ions allow us to keep ionic strength constant without affecting or creating a new quadruplex species. For comparison, we used $\mathrm{K}^{+}, \mathrm{Sr}^{2+}$ and $\mathrm{Pb}^{2+}$ cations. We performed UV melting 
experiments of $4 \mu \mathrm{M}$ G3T quadruplex with these cations. We used $4 \mu \mathrm{M}$ (a same of G3T) concentration of bivalent $\mathrm{Sr}^{2+}, \mathrm{Pb}^{2+}$ cations, and $100 \mu \mathrm{M}$ monovalent $\mathrm{K}^{+}$cations (Figure 2). Experiments revealed reversible two-state transitions (Figure S1). Unfold of G3T quadruplex with $\mathrm{K}^{+}$cations has a higher enthalpy change value, but $\mathrm{G} 3 \mathrm{~T}$ quadruplex with $\mathrm{Pb}^{2+}$ cations is a thermal more stable (Table 2). This result of enthalpy change value can be attributed to $\mathrm{K}^{+}$ cations form a higher number of bonds with G3T than $\mathrm{Sr}^{2+}$ and $\mathrm{Pb}^{2+}$ cations.

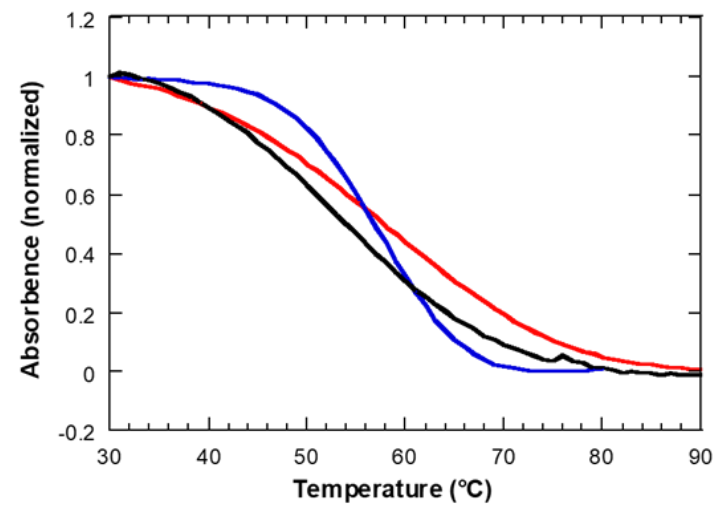

Figure 2 Normalized UV unfolding profiles of $4 \mu \mathrm{M}$ G3T in the presence of $4 \mu \mathrm{M} \mathrm{SrCl}_{2}$ (black), $4 \mu \mathrm{M} \mathrm{PbCl}_{2}$ (red) and $100 \mu \mathrm{M} \mathrm{KCl}$ (blue) in $10 \mathrm{mM}$ Tris- $\mathrm{HCl}$, pH 8.7.

Table 2. Melting of G3T in the presence of different cations.

\begin{tabular}{ccc}
\hline Cations - G3T & $T m\left({ }^{\circ} \mathrm{C}\right)$ & $\Delta H_{v H}(\mathrm{kcal} / \mathrm{mol})$ \\
\hline & & \\
$4 \mu \mathrm{M} \mathrm{Pb}^{2+}-4 \mu \mathrm{M}$ of d(GGGTGGGTGGGTGGG) & 57.5 & 36.5 \\
$100 \mu \mathrm{M} \mathrm{K}^{+}-4 \mu \mathrm{M}$ of d(GGGTGGGTGGGTGGG) & 56.7 & 50.1 \\
$4 \mu \mathrm{M} \mathrm{Sr}^{2+}-4 \mu \mathrm{M}$ of d(GGGTGGGTGGGTGGG) & 53.8 & 41.2 \\
\hline
\end{tabular}

$T m$ values (within $\pm 0.5^{\circ} \mathrm{C}$ ) and $\Delta H_{v H}$ (within $\pm 5 \%$ ) were derived from UV melting curves at a concentration of $4 \mu \mathrm{M} \mathrm{G} 3 \mathrm{~T}$; $4 \mu \mathrm{M} \mathrm{Pb}{ }^{2+}, 4 \mu \mathrm{M} \mathrm{Sr}{ }^{2+}$ and $100 \mu \mathrm{M} \mathrm{K}^{+}$; Buffer: $10 \mathrm{mM}$ Tris-HCl, pH 8.7.
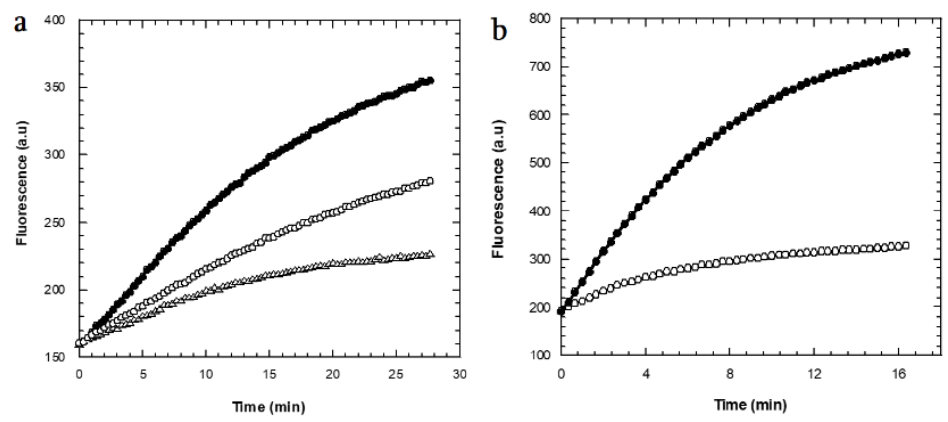

Figure 3. QPA reactions using a different cations with the Substrate3. a: $50 \mu \mathrm{M} \mathrm{Pb}^{2+}$ (filled circles); $10 \mathrm{mM} \mathrm{K}^{+}$ (open circles) and $50 \mu \mathrm{M} \mathrm{Sr}^{2+}$ (triangle), at $55^{\circ} \mathrm{C}$; b: $10 \mu \mathrm{M} \mathrm{Pb}^{2+}$ (filled circles); $25 \mathrm{mM} \mathrm{K}^{+}$(open circles), at $54{ }^{\circ} \mathrm{C}$; A buffer solution consisting of $10 \mathrm{mM}$ Tris- $\mathrm{HCl}$ at $\mathrm{pH} 8.7 ; 50 \mathrm{mM}$ monovalent cations, $2 \mathrm{mM} \mathrm{MgCl}_{2}$ Employing Vent (exo-) DNA polymerase.

In the next task, we have chosen the optimal cation for QPA. For comparison, we used the same concentration of bivalent $\mathrm{Sr}^{2+}, \mathrm{Pb}^{2+}$ cations, and $10-25 \mathrm{mM}$ of $\mathrm{K}^{+}$, which concentrations are optimal for QPA with $\mathrm{K}^{+}$cations [18]. In this experiment, the best rate of QPA was shown by using $\mathrm{Pb}^{2+}$ cations. QPA with $50 \mu \mathrm{M} \mathrm{Pb}^{2+}$ cations reveals $\sim 2$ times fast amplification than $50 \mu \mathrm{M}$ of $\mathrm{Sr}^{2+}$ cations and $\sim 1.5$ times fast amplification than $10 \mathrm{mM} \mathrm{K}+$ cations (Figure 3a). QPA with $10 \mu \mathrm{M} \mathrm{Pb}^{2+}$ cations demonstrate $\sim 3$ times fast amplification than $25 \mathrm{mM}$ of $\mathrm{K}^{+}$(Figure 3b). Based on it, we've applied $\mathrm{Pb}^{2+}$ cations for QPA.

We performed QPA measurements for the negative control with $\mathrm{Pb}^{2+}$ cations, which contains all reaction components except for the template. As expected, this measurement did 
not reveal amplification because a polymerase can't attach missing guanine to the primer without a duplex formation, and the primer is not able to fold the quadruplex (Figure 4).

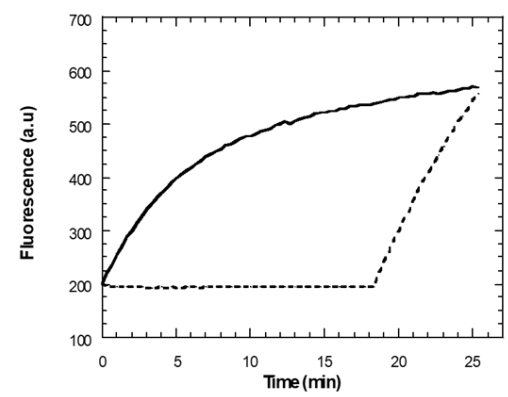

Figure 4. QPA reactions with a negative control. substrate 3 (line) and substrate 3 without template molecule (first 18 minutes), a template was added into the reaction mixture after 18 minutes (dashed line). $50 \mu \mathrm{M} \mathrm{PbCl}_{2}$, $50 \mathrm{mM} \mathrm{CsCl}, 2 \mathrm{mM} \mathrm{MgCl}$; Tris- $\mathrm{HCl} 10 \mathrm{mM} ; 800 \mu \mathrm{M}$ of dGTP ; Vent (exo-) at $59^{\circ} \mathrm{C}$.

We've determined the optimal concentration of $\mathrm{Pb}^{2+}$ for QPA at $37^{\circ} \mathrm{C}$. The maximum rate of QPA was shown by using $10 \mu \mathrm{M} \mathrm{Pb}^{2+}$ cations concentration. Thus, for Qpa reactions, we applied the following buffer: $10 \mu \mathrm{M} \mathrm{PbCl}_{2}, 50 \mathrm{mM} \mathrm{CsCl}, 2 \mathrm{mM} \mathrm{MgCl}_{2}$, Tris- $\mathrm{HCl} 10 \mathrm{Mm}$, $\mathrm{pH}$ 8.7. Cations play a key role and can have both positive and negative effects on QPA. As reported earlier, truncated versions of the G3T sequence (e.g., our primer) can fold some quadruplexes at higher $\mathrm{K}^{+}$concentrations, especially the sequence missing only one guanine [40]. Thus, the decrease in the QPA rate at higher than $25 \mu \mathrm{M} \mathrm{Pb}^{2+}$ cations can be attributed to the secondary structure of the primers, which impede the priming process of QPA.

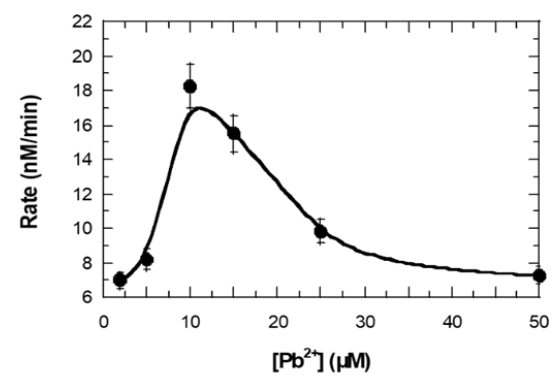

Figure 5. Optimal concentration of $\mathrm{Pb}^{2+}$ for QPA. QPA rate dependence on $\mathrm{Pb}^{2+}$ concentration using the Substrate 2. Primer/Template concentrations 300/3 nM. Measurements are carried out at $37{ }^{\circ} \mathrm{C}$ in $50 \mathrm{mM} \mathrm{CsCl}$,

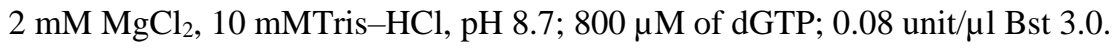

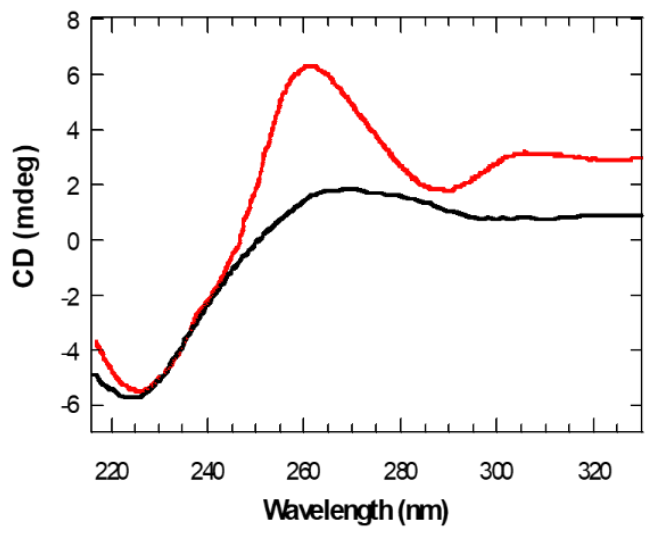

Figure 6. $\mathrm{CD}$ spectra of $2 \mu \mathrm{M}$ G3T with $12 \mu \mathrm{M} \mathrm{PbCl}_{2}$ at $35^{\circ} \mathrm{C}$ (red) and at $85^{\circ} \mathrm{C}$ (black); $10 \mathrm{mM}$ Tris- $\mathrm{HCl}, \mathrm{pH}$ 8.7 in $0.5 \mathrm{~cm}$ optical cuvette. 
At the same time, increasing $\mathrm{Pb}^{2+}$ concentration accelerates QPA by facilitating the dissociation of primers (Figure 5).

To determine the folding topology of G3T quadruplex induced by $\mathrm{Pb}^{2+}$ cations, we performed $\mathrm{CD}$ spectroscopy measurement for at different temperatures. $\mathrm{CD}$ spectra at $35^{\circ} \mathrm{C}$ demonstrate characteristics of parallel quadruplexes: a strong positive peak at $\sim 262 \mathrm{~nm}$ and a minor positive peak at $\sim 305 \mathrm{~nm}$. The next measurement at $85^{\circ} \mathrm{C}$ temperature at which quadruplexes are unfolded ( $T m$ of $2 \mu \mathrm{M} \mathrm{G} 3 \mathrm{~T}$ with $12 \mu \mathrm{M} \mathrm{Pb}^{2+}$ cations is $\sim 63^{\circ} \mathrm{C}$ ), reveals that a positive peak at $\sim 262 \mathrm{~nm}$ significantly reduced. A minor positive peak at $\sim 305 \mathrm{~nm}$ fully disappears (Figure 6).

\subsection{QPA at $35-45^{\circ} \mathrm{C}$ temperature interval.}

In this task, we've implemented Quadruplex priming amplification at $35-45{ }^{\circ} \mathrm{C}$ temperature interval. For this, we've tested three DNA polymerases: Taq, Vent (exo-), and Bst 3.0. As a result, show at $55^{\circ} \mathrm{C}$ rate of QPA is almost the same by all mentioned DNA polymerases, but at $37^{\circ} \mathrm{C}$ rate of QPA is a significantly low by Vent (exo-) DNA polymerase. The highest rate of QPA was detected using Bst 3 DNA polymerase. However, for the next experiments, we selected Bst 3 since it reveals the most rapid amplification (Figure 7).
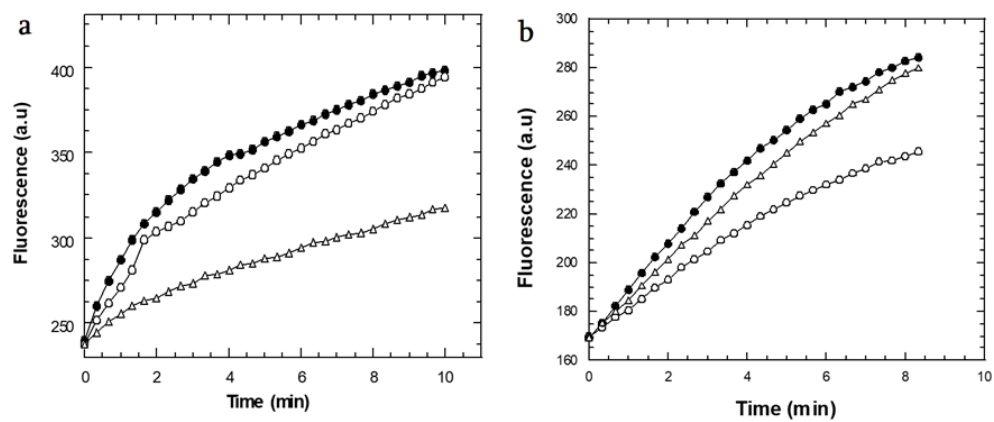

Figure 7. QPA reactions by different DNA polymerases: Bst 3.0 (filled circles), Taq (open circles), Vent (exo-) (triangle). a: Measurements are carried out with the Substrate 2 at $37^{\circ} \mathrm{C}$. b: Measurements are carried out with the Substrate 3 at $55^{\circ} \mathrm{C}$.

The substrate 2 reveals better amplification than substrate 1 at $40{ }^{\circ} \mathrm{C}$ temperature. In addition, we performed measurements for the negative control at this temperature, which contains all reaction components except for the template (Figure S2). To determine QPA efficiency at $37^{\circ} \mathrm{C}$ we performed measurements for low concentrations of template molecule using substrate 2 . As the results show, linear QPA at $37^{\circ} \mathrm{C}$ allows detection of $10 \mathrm{pM}$ template molecule in less than one hour (Figure 8).

Considering the cases discussed above, we carried out QPA reactions at $33-47{ }^{\circ} \mathrm{C}$ temperature with an average 2-degree interval using the Substrate 2. QPA was monitored by fluorescence of $3 \mathrm{MI}$ incorporated in the fourth position of the primers. A reaction mixture containing $300 \mathrm{nM}$ primer, $3 \mathrm{nM}$ and $1 \mathrm{nM}$ template. We determined the average value of the QPA rate. The results show an optimal rate of QPA, at the maximum $41{ }^{\circ} \mathrm{C}$, the rate reaches $21 \mathrm{nM} / \mathrm{min}$ for $300 / 3 \mathrm{~nm}$ Primer/template concentrations and $10 \mathrm{nM} / \mathrm{min}$ for $300 / 1 \mathrm{~nm}$. The temperature dependence of QPA rates closely correlates with the melting behavior of the complexes, which agrees with the idea that the nature of QPA is determined by the thermal stabilities of the primer/template complexes before and after elongation [3]. 


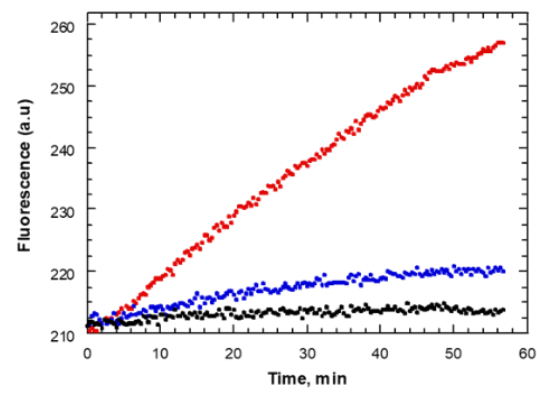

Figure 8. QPA reactions at low concentrations of template molecule using Substrate 2, Primer $200 \mathrm{~nm}$, template: $100 \mathrm{pM}$ (open square), $10 \mathrm{pM}$ (triangle) and negative control (filled square). Employing $0.08 \mathrm{unit} / \mu \mathrm{l}$

Bst 3.0, $800 \mu \mathrm{M}$ of dGTP in $10 \mu \mathrm{M} \mathrm{PbCl}_{2}, 50 \mathrm{mM} \mathrm{CsCl}, 2 \mathrm{mM} \mathrm{MgCl}_{2}$, Tris- $\mathrm{HCl} 10 \mathrm{Mm}, \mathrm{pH} 8.7$ at $37^{\circ} \mathrm{C}$.

Isothermal QPA requires both efficient priming and duplex dissociation at the same temperature. For instance, substrate 2 demonstrates good activity between $35-45^{\circ} \mathrm{C}$ and strong activity $37-43{ }^{\circ} \mathrm{C}$ (Figure 9), which means that both processes take place at these temperatures.

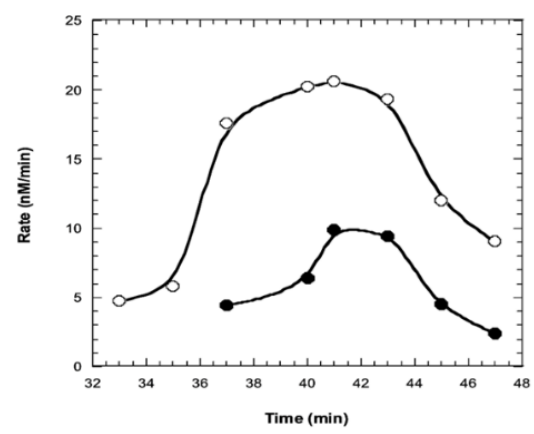

Figure 9. Temperature dependence of QPA rates using the Substrate 2 listed in Table 1. Primer/template concentrations: 300/3 $\mathrm{nM}$ (open circles) and 300/1 nM (filled circles); employing 0.08 unit/ $\mu$ l Bst 3.0, $800 \mu \mathrm{M}$ of dGTP in $10 \mu \mathrm{M} \mathrm{PbCl}_{2}, 50 \mathrm{mM} \mathrm{CsCl}, 2 \mathrm{mM} \mathrm{MgCl}$, Tris- $\mathrm{HCl} 10 \mathrm{Mm}, \mathrm{pH}$ 8.7.

\section{Conclusions}

In the present work, we designed linear QPA assays at a range of $35-45^{\circ} \mathrm{C}$. Substrate 2 (table 1) demonstrates strong activity at a range of $37-43{ }^{\circ} \mathrm{C}$ temperature, which allows the detection of $10 \mathrm{pM}$ template molecules in less than one hour. Bst 3 DNA polymerase demonstrates an optimal rate of QPA at $55{ }^{\circ} \mathrm{C}$ as well as at $37{ }^{\circ} \mathrm{C}$ temperature. As the results show, QPA with lead cations reveal $\sim 3$ times fast amplification than potassium cations. Experiments by UV-Visible and $\mathrm{CD}$ spectroscopy demonstrate that $\mathrm{G} 3 \mathrm{~T}$ with $\mathrm{Pb}^{2+}$ cations form a stable parallel quadruplex: Tm of $4 \mu \mathrm{M}$ G3T quadruplex with $4 \mu \mathrm{M} \mathrm{Pb}^{2+}$ cations $\sim 57{ }^{\circ} \mathrm{C}$. QPA can be applied as a method for the implementation of simple and cheap diagnostics (POC), as well as development at a range of $35-45{ }^{\circ} \mathrm{C}$, which will make this method more convenient for using it in nucleic acid-based diagnostics.

\section{Funding}

This work was supported by the Shota Rustaveli National Science Foundation of Georgia (SRNSFG) [YS17_102].

\section{Acknowledgments}

Thanks for the support of Ilia State University and the Shota Rustaveli National Science Foundation of Georgia (SRNSFG) [YS17_102]. 


\section{Conflicts of Interest}

The authors declare no conflict of interest.

\section{References}

1. Kankia, B.I. Self-dissociative primers for nucleic acid amplification and detection based on DNA quadruplexes with intrinsic fluorescence. Analytical Biochemistry 2011, 409, 59-65, https://doi.org/10.1016/j.ab.2010.10.011.

2. Lomidze, L.; Williford, T.H.; Musier-Forsyth, K.; Kankia, B. Isothermal amplification of long DNA segments by quadruplex priming amplification. Analytical Methods 2018, 10, 2972-2979, https://doi.org/10.1039/C8AY00843D.

3. Gogichaishvili, S.; Johnson, J.; Gvarjaladze, D.; Lomidze, L.; Kankia, B. Isothermal amplification of DNA using quadruplex primers with fluorescent pteridine base analogue 3-methyl isoxanthopterin. Biopolymers 2014, 101, 583-590, https://doi.org/10.1002/bip.22421.

4. Hawkins, M.E. Synthesis, purification and sample experiment for fluorescent pteridine-containing DNA: tools for studying DNA interactive systems. Nature Protocols 2007, 2, 1013-1021, https://doi.org/10.1038/nprot.2007.150.

5. Mazzini, S.; Gargallo, R.; Musso, L.; De Santis, F.; Aviñó, A.; Scaglioni, L.; Eritja, R.; Di Nicola, M.; Zunino, F.; Amatulli, A.; Dallavalle, S. Stabilization of c-KIT G-Quadruplex DNA Structures by the RNA Polymerase I Inhibitors BMH-21 and BA-41. International Journal of Molecular Sciences 2019, 20, https://doi.org/10.3390/ijms20194927.

6. D'Atri, V.; Gabelica, V. DNA and RNA telomeric G-quadruplexes: what topology features can be inferred from ion mobility mass spectrometry? Analyst 2019, 144, 6074-6088, https://doi.org/10.1039/C9AN01216H.

7. Li, D.; Peng, P.; Yang, Z.; Lv, B. Formation of G-quadruplex structure in supercoiled DNA under molecularly crowded conditions. RSC Advances 2019, 9, 26248-26251, https://doi.org/10.1039/C9RA06370F.

8. Puig Lombardi, E.; Holmes, A.; Verga, D.; Teulade-Fichou, M.-P.; Nicolas, A.; Londoño-Vallejo, A. Thermodynamically stable and genetically unstable G-quadruplexes are depleted in genomes across species. Nucleic Acids Res 2019, 47, 6098-6113, https://doi.org/10.1093/nar/gkz463.

9. Jansson, L.I.; Hentschel, J.; Parks, J.W.; Chang, T.R.; Lu, C.; Baral, R.; Bagshaw, C.R.; Stone, M.D. Telomere DNA G-quadruplex folding within actively extending human telomerase. Proceedings of the National Academy of Sciences 2019, 116, 9350-9359, https://doi.org/10.1073/pnas.1814777116.

10. Zhang, J., Xia, Y., Hao, Y. and Tan Z. DNA:RNA hybrid G-quadruplex formation upstream of transcription start site. Sci Rep 2020,10, 7429. https://doi.org/10.1038/s41598-020-64117-X.

11. Ma, T. Z., Zhang, M. J., Liao, T. C., Li, J. H., Zou, M., Wang, Z. M., and Zhou, C. Q. Dimers formed with the mixed-type G-quadruplex binder pyridostatin specifically recognize human telomere G-quadruplex dimers. Organic \& biomolecular chemistry 2020, 18(5), 920-930. https://doi.org/10.1039/c9ob02470k

12. Tan, J., Lan, L. The DNA secondary structures at telomeres and genome instability. Cell \& Bioscience 2020, 10, 47. https://doi.org/10.1186/s13578-020-00409-z.

13. Hong-Liang B. and Yan X. Telomeric DNA-RNA-hybrid G-quadruplex exists in environmental conditions of HeLa cells. Chem. Commun. 2020, 56, 6547-6550, https://doi.org/10.1039/D0CC02053B.

14. Wu, W. Q., Zhang, M. L., and Song, C. P. A comprehensive evaluation of a typical plant telomeric Gquadruplex (G4) DNA reveals the dynamics of G4 formation, rearrangement, and unfolding. The Journal of biological chemistry 2020, 295(16), 5461-5469. https://doi.org/10.1074/jbc.RA119.012383.

15. Jing, N.; Rando, R.F.; Pommier, Y.; Hogan, M.E. Ion Selective Folding of Loop Domains in a Potent AntiHIV Oligonucleotide. Biochemistry 1997, 36, 12498-12505, https://doi.org/10.1021/bi962798y.

16. Varshney, D.; Spiegel, J.; Zyner, K.; Tannahill, D.; Balasubramanian, S. The regulation and functions of DNA and RNA G-quadruplexes. Nature Reviews Molecular Cell Biology 2020, https://doi.org/10.1038/s41580-020-0236-x.

17. Zaccaria, F.; Fonseca Guerra, C. RNA versus DNA G-Quadruplex: The Origin of Increased Stability. Chemistry - A European Journal 2018, 24, 16315-16322, https://doi.org/10.1002/chem.201803530.

18. Taylor, A.; Joseph, A.; Okyere, R.; Gogichaishvili, S.; Musier-Forsyth, K.; Kankia, B. Isothermal quadruplex priming amplification for DNA-based diagnostics. Biophysical Chemistry 2013, 171, 1-8, http://dx.doi.org/10.1016/j.bpc.2012.11.001.

19. Niemz, A.; Ferguson, T.M.; Boyle, D.S. Point-of-care nucleic acid testing for infectious diseases. Trends in Biotechnology 2011, 29, 240-250, https://doi.org/10.1016/j.tibtech.2011.01.007.

20. Kong, H.; Kucera, R.B.; Jack, W.E. Characterization of a DNA polymerase from the hyperthermophile archaea Thermococcus litoralis. Vent DNA polymerase, steady state kinetics, thermal stability, processivity, strand displacement, and exonuclease activities. J Biol Chem 1993, 268, 1965-1975. 
21. Mattila, P.; Korpela, J.; Tenkanen, T.; Pitkämem, K. Fidelity of DNA synthesis by the Thermococcus litoralis DNA polymerase - an extremely heat stable enzyme with proofreading activity. Nucleic Acids Res 1991, 19, 4967-4973, https://doi.org/10.1093/nar/19.18.4967.

22. Eckert, K.A.; Kunkel, T.A. DNA polymerase fidelity and the polymerase chain reaction. PCR Methods and Applications 1991, 1, 17-24, https://doi.org/10.1101/gr.1.1.17.

23. Mergny, J.L.; Phan, A.T.; Lacroix, L. Following G-quartet formation by UV-spectroscopy. FEBS Letters 1998, 435, 74-78, https://doi.org/10.1016/s0014-5793(98)01043-6.

24. Lv, M.; Guo, Y.; Ren, J.; Wang, E. Exploration of intramolecular split G-quadruplex and its analytical applications. Nucleic Acids Res 2019, 47, 9502-9510, https://doi.org/10.1093/nar/gkz749.

25. Saad, M.; Guédin, A.; Amor, S.; Bedrat, A.; Tourasse, N.J.; Fayyad-Kazan, H.; Pratviel, G.; Lacroix, L.; Mergny, J.L. Mapping and characterization of G-quadruplexes in the genome of the social amoeba Dictyostelium discoideum. Nucleic Acids Res 2019, 47, 4363-4374, https://doi.org/10.1093/nar/gkz196.

26. Marchand, A.; Rosu, F.; Zenobi, R.; Gabelica, V. Thermal Denaturation of DNA G-Quadruplexes and Their Complexes with Ligands: Thermodynamic Analysis of the Multiple States Revealed by Mass Spectrometry. Journal of the American Chemical Society 2018, 140, 12553-12565, https://doi.org/10.1021/jacs.8b07302.

27. Marky, L.A.; Breslauer, K.J. Calculating thermodynamic data for transitions of any molecularity from equilibrium melting curves. Biopolymers 1987, 26, 1601-1620 https://doi.org/10.1002/bip.360260911.

28. Mathias, J.; Okyere, R.; Lomidze, L.; Gvarjaladze, D.; Musier-Forsyth, K.; Kankia, B. Thermal stability of quadruplex primers for highly versatile isothermal DNA amplification. Biophysical Chemistry 2014, 185, 14-18, http://dx.doi.org/10.1016/j.bpc.2013.10.008.

29. Matsugami, A.; Ouhashi, K.; Kanagawa, M.; Liu, H.; Kanagawa, S.; Uesugi, S.; Katahira, M. An intramolecular quadruplex of (GGA)4 triplet repeat DNA with a G:G:G:G tetrad and a G(:A):G(:A):G(:A):G heptad, and its dimeric interaction 11Edited by I. Tinoco. Journal of Molecular Biology 2001, 313, 255-269, https://doi.org/10.1006/jmbi.2001.5047.

30. Paramasivan, S.; Rujan, I.; Bolton, P.H. Circular dichroism of quadruplex DNAs: Applications to structure, cation effects and ligand binding. Methods 2007, 43, 324-331, https://doi.org/10.1016/j.ymeth.2007.02.009.

31. Rocca, R.; Palazzesi, F.; Amato, J.; Costa, G.; Ortuso, F.; Pagano, B.; Randazzo, A.; Novellino, E.; Alcaro, S.; Moraca, F.; Artese, A. Folding intermediate states of the parallel human telomeric G-quadruplex DNA explored using Well-Tempered Metadynamics. Scientific Reports 2020, 10, https://doi.org/10.1038/s41598020-59774-x.

32. Hardin, C.C.; Corregan, M.J.; Lieberman, D.V.; Brown, B.A. Allosteric Interactions between DNA Strands and Monovalent Cations in DNA Quadruplex Assembly: Thermodynamic Evidence for Three Linked Association Pathways. Biochemistry 1997, 36, 15428-15450, https://doi.org/10.1021/bi970488p.

33. Lu, M.; Guo, Q.; Kallenbach, N.R. Thermodynamics of G-tetraplex formation by telomeric DNAs. Biochemistry 1993, 32, 598-601, https://doi.org/1021/bi00053a027.

34. Phan, A.T.; Kuryavyi, V.; Ma, J.B.; Faure, A.; Andreola, M.L.; Patel, D.J. An interlocked dimeric parallelstranded DNA quadruplex: a potent inhibitor of H IV-1 integrase. Proc Natl Acad Sci U S A 2005, 102, 634639, https://doi.org/10.1073/pnas.0406278102.

35. Kankia, B.; Gvarjaladze, D.; Rabe, A.; Lomidze, L.; Metreveli, N.; Musier-Forsyth, K. Stable Domain Assembly of a Monomolecular DNA Quadruplex: Implications for DNA-Based Nanoswitches. Biophys $J$ 2016, 110, 2169-2175, https://doi.org/10.1016/j.bpj.2016.04.031.

36. Benabou, S.; Mazzini, S.; Aviñó, A.; Eritja, R.; Gargallo, R. A pH-dependent bolt involving cytosine bases located in the lateral loops of antiparallel G-quadruplex structures within the SMARCA4 gene promotor. Scientific Reports 2019, 9, https://doi.org/10.1038/s41598-019-52311-5.

37. Johnson J, Okyere R, Joseph A, Musier-Forsyth K and Kankia B. Quadruplex formation as a molecular switch to turn on intrinsically fluorescent nucleotide analogs. Nucleic Acids Res. 2013;41(1):220-228. doi:10.1093/nar/gks975.

38. Lee, J.S. The stability of polypurine tetraplexes in the presence of mono- and divalent cations. Nucleic Acids Res 1990, 18, 6057-6060, https://doi.org/10.1093/nar/18.20.6057.

39. Paris G. and Picaud F. On the perfect diameter condition to optimize the antibiotic nanoencapsulation: case ofgramicidin. Letters in Applied NanoBioScience 2019, Volume 8, Issue 3, 2019, 654 - 660. https://doi.org/10.33263/LIANBS83.654660.

40. Kelley, S.; Boroda, S.; Musier-Forsyth, K.; Kankia, B.I. HIV-integrase aptamer folds into a parallel quadruplex: A thermodynamic study. Biophysical Chemistry 2011, 155, 82-88, https://doi.org/10.1016/j.bpc.2011.03.004. 


\section{Supplementary files}

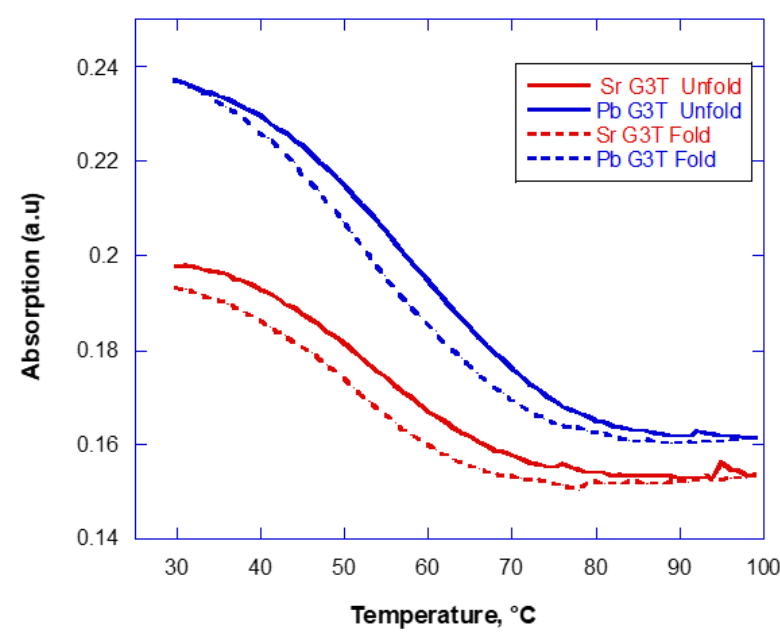

Figure S1. UV unfolding profiles of $4 \mu \mathrm{M}$ G3T in the presence of $4 \mu \mathrm{M} \mathrm{SrCl}_{2}$ (red), $4 \mu \mathrm{M} \mathrm{PbCl}_{2}$ (blue) in 10 $\mathrm{mM}$ Tris- $\mathrm{HCl}, \mathrm{pH} 8.7$.

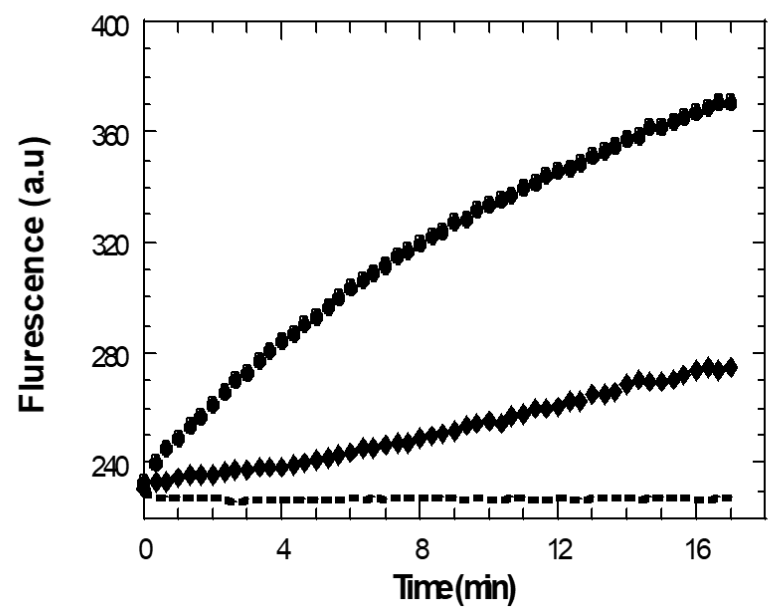

Figure S2. QPA reactions using the Substrate1 (rhombus), the Substrate2 (filled circles) and Negative controlwithout template molecule (dashed line); Employing Bst 3 DNA polymerase at $40{ }^{\circ} \mathrm{C}$. 